\title{
STABILIZATION OF BORIC ACID BUFFERS BY AERATION
}

\author{
By Edna H. Fawcett and S. F. Acree
}

\section{ABSTRACT}

This paper describes a method of stabilizing the commonly used $M / 20$ boric acid- $M / 20$ potassium chloride-sodium hydroxide buffer mixtures by aerating them with ordinary fresh air until they reach a state of equilibrium with atmospheric $\mathrm{CO}_{2}$.

A series of buffers ranging from $\mathrm{pH} 7.8$ to $\mathrm{pH} 11.65$ were prepared, and their values determined electrometrically. These buffers were then aerated until no further change in $\mathrm{pH}$ could be detected on repeating the electrode tests.

$\mathrm{A}$ table is given showing the initial $\mathrm{pH}$ readings and the changes in $\mathrm{pH}$ at different intervals of time during the aeration process.

Curves were plotted both from the initial and from the final series of readings, and are shown in a text figure.

Air-stable $M / 20$ buffer standards of any desired $\mathrm{pH}$ may be prepared by adding the required volumes of $N / 5 \mathrm{NaOH}$ read from the "equilibrium curve" to $50 \mathrm{ml}$ portions of the $M / 5 \mathrm{H}_{3} \mathrm{BO}_{3}-\mathrm{KCl}$ buffer mixture, diluting to $200 \mathrm{ml}$ and aerating the resulting solutions for the periods of time shown to be necessary. From 2 to 6 days are required to reach equilibrium according to the $\mathrm{pH}$ of the $M / 20$ buffer.

The alkaline limit for air-stable $M / 20$ boric acid buffers is $\mathrm{pH} 9.4$.

The ionization constant of boric acid was calculated from the data and found to be $K a=0.75 \times 10^{-9}$.

\section{CONTENTS}

I. Introduction

II. Method of $\mathrm{pH}$ measurement

III. Preparation of solutions

IV. Method of aeration

V. Calculation of the ionization or activity constant of boric acid..... 762

VI. Summary

\section{INTRODUCTION}

The need for stable buffers for colorimetric $\mathrm{pH}$ measurements in the alkaline range, $\mathrm{pH} 8$ to 10 , suggested the possibility of stabilizing the usual $M / 20$ boric acid- $M / 20$ potassium chloride-sodium hydroxide buffer mixtures, which have been found unsatisfactory in general practice because of their change in the acid direction upon standing. Since preliminary observations ${ }^{1}$ had shown this change to be due to the action of atmospheric $\mathrm{CO}_{2}$ and since it is impossible to prepare any carbonate-free buffer mixture in the alkaline range which would not be so affected, it was suggested by us earlier to add calculated mixtures of alkali-carbonate-bicarbonate to keep the buffer air stable at a given $\mathrm{pH}$ or to aerate it completely during the $\mathrm{pH}$ adjustment. The attempt, has, therefore, been made to bring a series of boric acid buffers covering the above range into equilibrium with the $\mathrm{CO}_{2}$ of the air by aeration. The buffers were desired for use as $\mathrm{pH}$ standards,

1 This series: Fawcett, Edna H., and Acree, S. F., J. Bact., 17, p. 163-204; 1929. Acree, S. F., and Fawcett, Edna H., J. Ind. Eng. Chem., 2, p. 78-99; 1930. 
and especially for experiments to be reported in another article on the salt errors or changes in activities of indicators and buffers as the latter are diluted from $M / 1$ to $M / 10,000$.

\section{METHOD OF pH MEASUREMENT}

All pH determinations were made on the Acree double hydrogen clectrode by using as a standard a $M / 10$ sodium acid phthalate solution which had been carefully checked against a calomel cell. The readings were sharp in nearly every determination made and accurately reproducible. Only in the case of the last two or three buffers at the allialine end of the series was there any tendency for the readings to "run down" owing to driving out of $\mathrm{CO}_{2}$ under partial pressure by the rapidly bubbling hydrogen, and this change was not more than about $1 \mathrm{mv}$. in 10 minutes after equilibrium had been reached. Five minute readings, therefore, were accepted in these cases, since we have found this amount of time sufficient for attaining equilibrium with this apparatus when the electrodes are fully saturated in the beginning.

The initial pH curve for the unaerated solutions was extended beyond the usual range for boric acid buffer-standards in order to determine the limit of the buffering power of boric acid against carhonates in equilibrium with atmospheric $\mathrm{CO}_{2}$ by aeration and at the same time determine how far in the alkaline direction a series of airstable buffers might be prepared by this method.

\section{PREPARATION OF SOLUTIONS}

The buffers used in preparing the solutions were C. P. chemicals recrystallized as stated in Tables 1 and 2 . The $N / 5$ sodium hydroxide was carefully compared with a standard sample of potassium-acid phthalate furnished by the National Bureau of Standards. Two different samples of boric acid (designated as 1 and 2) and two different samples of potassium chloride (likewise designated as 1 and 2) were recrystallized three different times, the different recrystallizations being designated as $a, b$ and $c . M / 5$ solutions of these compounds were made up from the different crops of crystals for use in determining the effect of the number of recrystallizations on the $\mathrm{pH}$ values. Solution labeled $1 b$, for example, is made from sample 1 of boric acid and sample 1 of potassium chloride, each recrystallized twice $(b)$. The $M / 20$ borate buffers were then made up by adding graded volumes of $N / 5$ sodium hydroxide to $50 \mathrm{ml}$ portions of any of these solutions as desired and diluting to $200 \mathrm{ml}$. Double distilled, ('( $\mathrm{C}_{2}$-free, $\mathrm{pH} 7$ water was used in making all these solutions. Table 1 shows agreement, in the few comparative tests made, between PII readings on buffer mixtures representing the different samples of salts in the various stages of purification, but with additions of equal quantities of the $N / 5 \mathrm{NaOH}$. The $\mathrm{pH}$ values for the $M / 5$ boric acid-potassium chloride solutions without added alkali were determined with isohydric indicators and in one instance also with the hydrogen electrode. Colorimetric and electrometric values agree as closely as can be expected of such weakly acid solutions and further confirm the purity of the chemicals. The isohydric indicator method is better than the electrometric procedure for such cases. ${ }^{2}$

IF nоте4 nn I A troe, J. Bact., 17, p. 163; 1920. J. Ind. Eng. Chem., Anal. ed., 2, p. 78; 1930. 
TABLE 1.-Agreement in $p H$ Values of Solutions of Different Samples of Boric Acid and Potassium Chloride

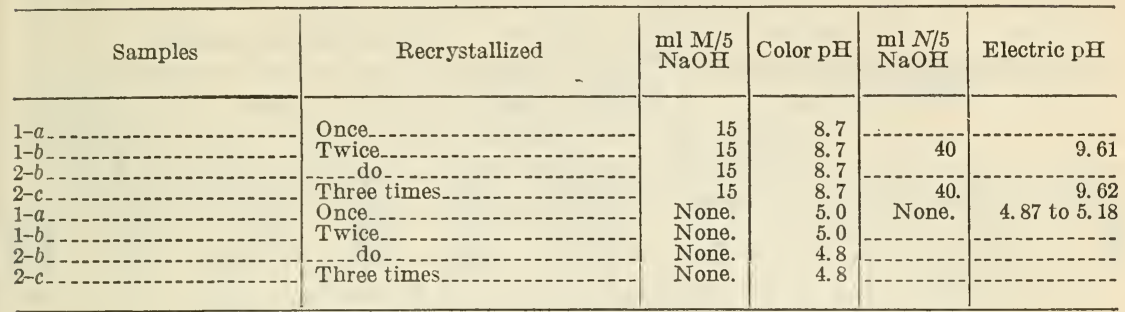

Table 2 and curve $A$ in Figure 1 give the $\mathrm{pH}$ values of the series of unaerated $M / 20$ buffers prepared from solutions $1-a, 1-b$, and $2-c$ (series I, II, and III). The $\mathrm{pH}$ readings fall somewhat lower in every instance than the values given by another worker and shown in curve $C$ of Figure $1 .^{3}$

\section{METHOD OF AERATION}

The graded series of boric acid solutions were aerated in the following way: A stream of fresh air from the pressure cock was led through (1) a side arm flask filled with absorbent cotton to remove possible dust or grease from the air and (2) through a flask of distilled water to take up moisture and lessen evaporation of the buffer, and thence in to the aeration bottle containing the buffer solution through which it was allowed to bubble freely. The level of the liquid in the bottle was marked and the loss, which was small, was made up from time to time by addition of pure distilled water. Table 2 shows the change in $\mathrm{pH}$ on aeration at different points on the curve and the length of time required to bring the buffers to air-equilibrium. In Series I checks were made daily in order to ascertain how long aeration would have to be carried on to accomplish this result. In Series II determinations were not made until the fourth day with subsequent checks to discover any further change. It will be noted that the more alkaline the buffer the greater the change in $\mathrm{pH}$ and also that the changes and attainment of equilibrium are very slow at the alkaline end of the series after the first rapid falling off has taken place. The fact that the "equilibrium" $\mathrm{pH}$ curve tends to become nearly a straight line at $50 \mathrm{ml}$ buffer to $50 \mathrm{ml}$ alkali in contrast to the very rapid rise at this point in the other curve giving initial measurements on the unaerated solution (see fig. 1) shows that boric acid reaches its practical limit as a buffer for carbonates in this region; that is, at about $\mathrm{pH} 9.4$.

${ }^{3}$ Clark and Lubs, J. Bact., 2, pp. 1, 109, 191; 1917. Clark, Determination of Hydrogen Ions. Williams \& Wilkins, Baltimore. 
TABLE 2.-Change of $p H$ of $M / 20$ boric acid buffers upon aeration Series I (COMMERCIAL BUFFERS ONCE RECRYTSALLIZED, 1-a)

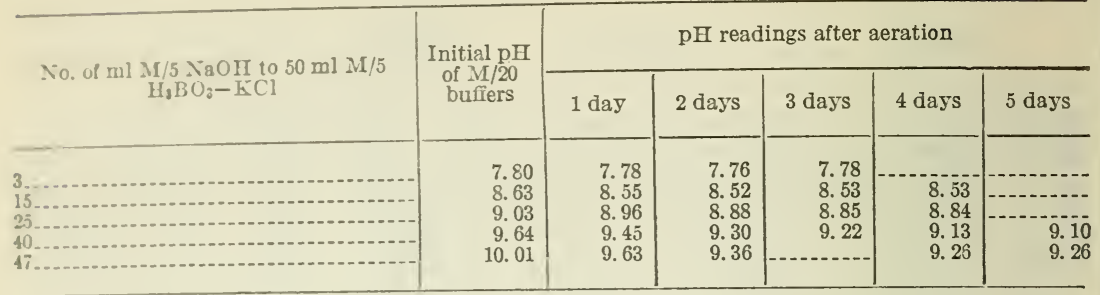

Series II (COMMERCIAL BUFFERS TWICE RECRYSTALLIZED, 1-b)

\begin{tabular}{|c|c|c|c|c|c|c|c|c|c|}
\hline \multirow{2}{*}{$\begin{array}{l}\text { No. of } \mathrm{ml} \mathrm{M} / 5 \mathrm{NaOH} \text { to } \\
50 \mathrm{ml} \mathrm{M} / 5 \mathrm{H}, \mathrm{BO}_{3}-\mathrm{Kl}\end{array}$} & \multirow{2}{*}{$\begin{array}{c}\text { Initial } \mathrm{pH} \\
\text { of } \mathrm{M} / 20 \\
\text { buffers }\end{array}$} & \multicolumn{6}{|c|}{$\mathrm{pH}$ readings after aeration } & \multicolumn{2}{|c|}{$\begin{array}{l}\mathrm{pH} \text { readings } \\
\text { after standing }\end{array}$} \\
\hline & & 4 days & 5 days & 6 days & 8 days & 11 days & 17 days & $\begin{array}{c}\text { Time } \\
\text { elapsed }\end{array}$ & $\mathrm{pH}$ \\
\hline $\begin{array}{l}5 \\
15 \\
25 \\
35 \\
40\end{array}$ & $\begin{array}{l}8.01 \\
8.67 \\
9.00 \\
9.37 \\
9.61\end{array}$ &  & $\begin{array}{l}8.55 \\
8.72 ? \\
9.02 \\
9.14\end{array}$ &  & $\frac{8.55}{9.14}$ & $\begin{array}{r}7.96 \\
8.85 \\
9.05\end{array}$ &  & $\begin{array}{r}\text { Weeks } \\
3 \\
2 \\
3 \\
3 \\
2\end{array}$ & $\begin{array}{l}7.97 \\
8.54 \\
8.86 \\
9.06 \\
9.15\end{array}$ \\
\hline $\begin{array}{l}47 \\
50 \\
55 \\
60\end{array}$ & $\begin{array}{l}10.00 \\
10.37 \\
11.03 \\
11.30 \\
11.65\end{array}$ & $\begin{array}{l}9.32 \\
9.39 \\
9.43 \\
9.53\end{array}$ & $\begin{array}{l}9.24 \\
9.31 \\
9.38 \\
9.39 \\
9.49\end{array}$ & $\begin{array}{l}9.31 \\
9.34 \\
9.38 \\
9.43\end{array}$ & 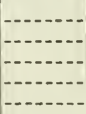 &  & $\begin{array}{l}9.24 \\
9.29 \\
9.34 \\
9.37\end{array}$ & $\begin{array}{l}6 \\
6 \\
6 \\
6 \\
6\end{array}$ & $\begin{array}{r}9.24 \\
9.36 \\
9.40\end{array}$ \\
\hline
\end{tabular}

Serles III (COMMERCIAL BUFFERS RECRYSTALLIZED THREE TIMES, 2-c)

\begin{tabular}{|c|c|c|c|c|c|c|c|c|}
\hline \multirow{2}{*}{$\begin{array}{c}\text { No. of } \mathrm{ml} \mathrm{M} / 5 \mathrm{NaOH} \text { to } 50 \mathrm{ml} \\
\mathrm{M} / 5 \mathrm{H}_{2} \mathrm{BO}_{3}-\mathrm{KCl}\end{array}$} & \multirow{2}{*}{$\begin{array}{c}\text { Initial pH } \\
\text { of } M / 20 \\
\text { buffers }\end{array}$} & \multicolumn{3}{|c|}{$\begin{array}{l}\mathrm{pH} \text { readings after } \\
\text { aeration }\end{array}$} & \multicolumn{2}{|c|}{$\begin{array}{l}\text { pH after stand- } \\
\text { ing }\end{array}$} & \multicolumn{2}{|c|}{$\begin{array}{l}\mathrm{pH} \text { on further } \\
\text { aeration }\end{array}$} \\
\hline & & 2 days & 3 days & 5 days & $\begin{array}{c}\text { Time } \\
\text { elapsed }\end{array}$ & $\mathrm{pH}$ & $\underset{\text { aerated }}{\text { Time }}$ & $\mathrm{pH}$ \\
\hline 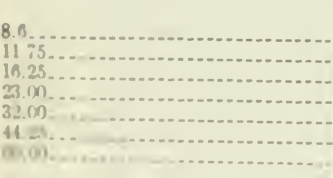 & $\begin{array}{r}8.29 \\
8.50 \\
8.71 \\
8.97 \\
9.28 \\
9.82 \\
11.51\end{array}$ & 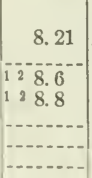 & 8.43 & $\begin{array}{r}- \\
29.0 \\
29.2 \\
29.4\end{array}$ & $\begin{array}{r}\text { Weeks } \\
6 \\
6 \\
6 \\
6 \\
6 \\
6 \\
6\end{array}$ & $\begin{array}{l}8.28 \\
8.47 \\
8.64 \\
8.83 \\
9.04 \\
9.25 \\
9.46\end{array}$ & $\begin{array}{r}\text { Hours } \\
18 \\
18 \\
3 \\
18 \\
18\end{array}$ & $\begin{array}{r}18.24 \\
18.40 \\
9 \\
18.99 \\
9.28 \\
9.36\end{array}$ \\
\hline
\end{tabular}

Ierated with a porous alunilum thimble.

The realings were made colorimetrically against color standards prepared the same day from buffers whath heen checked two days proviously.

Hydrogen electrode measurements were made on this entire series with two exceptions after the buffers had stood for varying periods of time in Pyrex bottles closed with rather poorly fitting groundglass stoppers. The last column in Table 2 shows how great a degree of stability these aerated buffers possess and indicates the practicability of the method.

Series III, Table 2, represents an attempt to prepare a set of acrated horic acid buffers graded in steps of $0.2 \mathrm{pH}$ from $\mathrm{pH} 8.2$ to III 9.4 by the use of curve B. (Fig. 1.) The amounts of $M / 5$ $\mathrm{NaOH}$ given in column 1 were read from this curve $(B)$ and added 
to the $\mathrm{H}_{3} \mathrm{BO}_{3}-\mathrm{KCl}$ mixture $(2-\mathrm{c})$ as in Series I and II. The $\mathrm{pH}$ readings obtained after aeration and given in columns 3,4 , and 5 show that the desired values can be easily obtained by this method. These data are all the more valuable because Series III was prepared from different samples of chemicals and the readings on the unaerated (column 2) and aerated buffers fit in to curves $A$ and $B$ plotted originally from Series II as is shown in the figure.

The variations from the even intervals found in the last two columns are due partly, no doubt, to experimental error in making quantitative

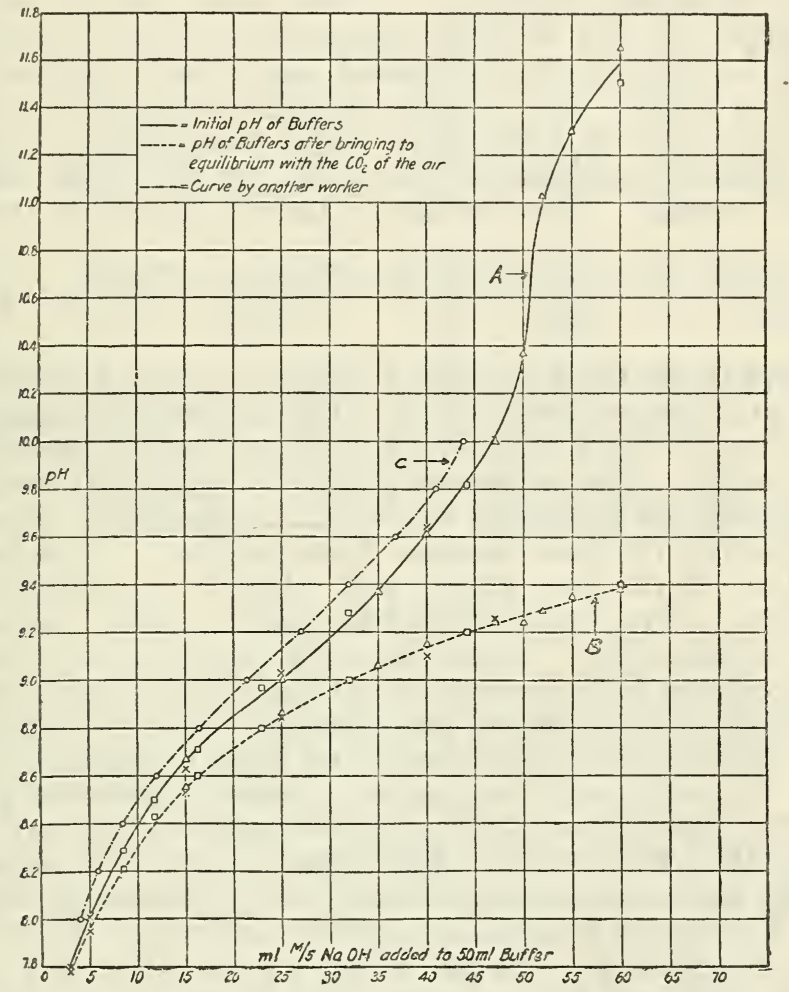

Figure 1

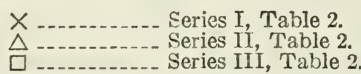

measurements either in preparing the buffer mixtures or at the electrode, but may also be partially explained by a difference in temperature, which is not corrected for in the colorimetric readings, or to variation in barometric pressure which would affect slightly the amount of $\mathrm{CO}_{2}$ dissolved in the solutions and hence the $\mathrm{pH}$. It is also probable that the buffers had not completely reached equilibrium in some instances and hence changed in the acid direction on further aeration as the figures in the last column seem to show with one exception. In any case the changes are far less than those taking: place in unaerated buffers in this $\mathrm{pH}$ range. A carefully prepared 
set of color standards contrining thymol blue which had stood six weeks showed no perceptible change when compared with a fresh set made from the same buffers.

\section{CALCULATION OF THE IONIZATION OR ACTIVITY CONSTANT OF BORIC ACID}

The abore $\mathrm{pH}$ measurements on the unaerated solutions can be used to calculate the ionization constant of boric acid within 5 per cent under the stated conditions. It is obvious that the exact ionization constant can not be fully evaluated until $\mathrm{pH}$ measurements, viscosities, and ionizations calculated from ionic mobilities and conductivities or from e. m. f. or freezing point data, are determined for solutions from $M / 1$ to $M / 10,000$ in order to establish the magnitude of the disturbing interionic forces or salt errors. Such data are not a vailable at present. The constant is hereby defined by the equation

$\mathrm{K} a=\frac{\mathrm{H}^{+} \times \mathrm{BO}_{2}}{\mathrm{HBO} \mathrm{O}_{2}}=\frac{\mathrm{H}^{+} \times \alpha \mathrm{NaBO}}{\mathrm{HBO}_{2}}=\frac{H^{+} \alpha\left(\mathrm{NaOH}-\mathrm{OH} / \alpha^{\prime}\right)}{H B O_{2}}$ in which $H^{+}$,

$\mathrm{BO}_{2}$, and $\mathrm{HBO}_{2}$ are the activities of the hydrogen and borate ions and free boric acid, respectively, and $\alpha$ is the fraction of ionization of the sodium borate, on the assumption that concentrations are proportional to the activities. The expression $\mathrm{NaBO}_{2}$ is practically equivalent to the alkali used and is exactly equivalent to the alkali added less the free alkali given by the correction factor $\mathrm{OH} / \alpha^{\prime} . \quad \alpha^{\prime}$ is the fraction of ionization of the free alkali, and $\mathrm{OH}$ the concentration of the hydroxyl ions. The value of $\alpha$ for the sodium borate varies with the amount of alkali added. If the isohydric principle is applied, $\alpha$ is the ionization of the $N / 20$ potassium chloride $-N / 20$ boric acid solution when no alkali has been added and decreases to that for an $N / 10$ solution when both $N / 20$ sodium borate and $N / 20$ potassium chloride are present. For such a small change in $\alpha$, namely, from 0.83 to approximately 0.77 , the values of $H^{+}$must be measured to within 1 or 2 per cent or the $\mathrm{pH}$ to within 0.005 to 0.01 unit to determine the real value of $K a$ and any change produced in it by increasing salt concentration. The values of $K a / \alpha$ in the fifth column of Table 3 are not constant enough to give the individual values of $K a$ to within 1 per cent. The work was not controlled closely enough for this purpose, but rather for practical uses to within 0.02 to $0.03 \mathrm{pH}$ unit. We see, however, that the values of $K a / \alpha$ show a maximum variation up and down of about 7 or 8 per cent and a mean deviation of 3 or 4 per cent from an average of $1 \times 10^{-9}$. In calculating the values of $K a / \alpha$ in column is the actual experimental data were used, and it was assumed that the weight of the boric acid used should require $50 \mathrm{ml}$. of alkali for exact neutralization. If the data for $\mathrm{NaBO}_{2}$ and $\mathrm{HBO}_{2}$ are taken from the smonth curve $A$ of Figure 1 the values of $\mathrm{Ka} / \alpha$ given in column 6 are slightly lower than those in column 5 . The values for fir $\alpha$ are calculated from curve $C$ and are given in column 7 for comparison. It would seem from inspection of the data in column 5 that the value of $K a / \alpha$ lies between 0.9 and $1 \times 10^{-9}$. $A$ few calculations have shown that the amount of alkali required to give any desired pH will vary 5 per cent with use of these two constants in the ionization equation given above. 'This is larger than the experimental 
error, and it would seem that a value around $0.95 \times 10^{-9}$ is to be preferred. As the average value of $\alpha$ in this range is about 0.80 we can use $K a=0.75 \times 10^{-9}$ for the present.

TABLE 3.-Ionization constant of boric acid

\begin{tabular}{|c|c|c|c|c|c|c|}
\hline \multirow{2}{*}{$\mathrm{pH}$} & \multirow{2}{*}{$\mathrm{H}^{+}$} & \multirow{2}{*}{$\mathrm{NaBO}_{3}$} & \multirow{2}{*}{$\mathrm{HBO}_{3}$} & \multicolumn{3}{|c|}{$10^{+9} \times K a / \alpha$ from -} \\
\hline & & & & $\begin{array}{c}\text { Actual } \\
\text { data }\end{array}$ & $\begin{array}{l}\text { Smooth } \\
\text { Curve A }\end{array}$ & Curve C \\
\hline $\begin{array}{l}7.8 \\
8.0 \\
8.2 \\
8.3\end{array}$ & $\begin{array}{l}10 \times 10^{-9} \\
5.31 \times 10^{-9} \\
5.13 \times 10^{-9}\end{array}$ & $\begin{array}{l}0.005 \\
.00725 \\
.00860\end{array}$ & $\begin{array}{r}0.04575 \\
.04350 \\
.04215\end{array}$ & $\begin{array}{l}\text { 1. } 110 \\
\text { 1. } 070 \\
1.065\end{array}$ & $\begin{array}{l}1.056 \\
1.060\end{array}$ & $\begin{array}{r}0.887 \\
.870 \\
.841\end{array}$ \\
\hline \multirow{2}{*}{$\begin{array}{l}8.4 \\
8.5 \\
8.6 \\
8.8\end{array}$} & $\begin{array}{l}3.98 \times 10^{-9}--- \\
3.16 \times 10^{-9}- \\
2.51 \times 10^{-9}=\end{array}$ & \multirow{2}{*}{$\begin{array}{l}.01016 \\
.01175 \\
.0137 \\
.0185\end{array}$} & \multirow{2}{*}{$\begin{array}{l}.04059 \\
.03900 \\
.03705 \\
.03225\end{array}$} & \multirow{2}{*}{$\begin{array}{r}1.015 \\
.971 \\
.948 \\
.931\end{array}$} & 1.001 & .821 \\
\hline & $1.585 \times 10^{-9}=$ & & & & .910 & .773 \\
\hline \multirow{2}{*}{$\begin{array}{l}9.0 \\
9.2 \\
9.28 \\
9.4\end{array}$} & $\begin{array}{l}1.000 \times 10^{-9} \\
6.31 \times 10^{-1} 0^{-} \\
5.25 \times 10^{-10}\end{array}$ & \multirow{2}{*}{$\begin{array}{l}.0250 \\
.0306 \\
.032 \\
.0356\end{array}$} & \multirow{2}{*}{$\begin{array}{l}.02575 \\
.02015 \\
.01875 \\
.01515\end{array}$} & \multirow{2}{*}{$\begin{array}{r}1.000 \\
.995 \\
.933 \\
.984\end{array}$} & $\begin{array}{l}.934 \\
.927\end{array}$ & $\begin{array}{l}.748 \\
.723\end{array}$ \\
\hline & $3.98 \times 10^{-1} 0^{-\ldots}$ & & & & .885 & .708 \\
\hline \multirow{2}{*}{$\begin{array}{c}9.6 \\
9.8 \\
9.82 \\
10.00\end{array}$} & $\begin{array}{l}2.51 \times 10^{-10} \\
1.585 \times 10^{-10}= \\
1.515 \times 10^{-10^{-}}\end{array}$ & \multirow{2}{*}{$\begin{array}{l}.03975 \\
.0436 \\
.04425 \\
.047\end{array}$} & \multirow{2}{*}{$\begin{array}{l}.01100 \\
.00715 \\
.00650 \\
.00375\end{array}$} & \multirow{2}{*}{$\begin{array}{r}.974 \\
1.080 \\
1.040 \\
(1.26)\end{array}$} & $\begin{array}{l}.882 \\
.966\end{array}$ & $\begin{array}{l}.704 \\
.703\end{array}$ \\
\hline & $1.000 \times 10^{-10}$ & & & & 1.027 & .718 \\
\hline & $\begin{array}{l}\text { Average } K a / \alpha \\
\text { If } \alpha=0.8, K a\end{array}$ & & & $\begin{array}{l}1.02 \times 10^{-9} \\
0.8 \times 10^{-9}\end{array}$ & $\begin{array}{l}0.96 \times 10^{-9} \\
0.75 \times 10^{-9}\end{array}$ & $\begin{array}{l}0.78 \times 10^{-9} \\
0.62 \times 10^{-9}\end{array}$ \\
\hline
\end{tabular}

\section{SUMMARY}

The commonly used $M / 20$ boric acid- $M / 20$ potassium chloridesodium hydroxide buffer mixtures can be stabilized by aerating them with ordinary fresh air until they reach a state of approximate equilibrium with atmospheric $\mathrm{CO}_{2}$.

Air-stable $M / 20$ buffer standards of any desired $\mathrm{pH}$ may be prepared with an accuracy within $0.05 \mathrm{pH}$ by adding the required volumes of $\mathrm{N} / 5 \mathrm{NaOH}$ read from the "equilibrium curve" to $50 \mathrm{ml}$ portions of the $M / 5 \mathrm{H}_{3} \mathrm{BO}_{3}-\mathrm{KCl}$ buffer mixture, diluting to $200 \mathrm{ml}$ and aerating the resulting solutions for the periods of time shown to be necessary. From 2 to 6 days are required to reach equilibrium according to the $\mathrm{pH}$ of the $M / 20$ buffer. With the position of the equilibrium curve $B$ now established, air-stable buffers of desired $\mathrm{pH}$ values can be prepared quickly by trial use of calculated bicarbonatecarbonate mixtures, or of pure carbon dioxide gas or of air under pressure sprayed into the liquid through an alundum thimble, followed by brief aeration with normal air.

The practical alkaline limit for air-stable $M / 20$ boric acid buffers is about $\mathrm{pH} 9.4$.

The ionization constant of boric acid was calculated from the data and found to be about $K a=0.75 \times 10-9$.

Washington, February 7, 1931. 